Diabetologia 9, 467-471 (1973)

(C) by Springer-Verlag 1973

\title{
Interaction between Serum Calcium Concentration and Glucose Tolerance in Normal and Azotaemic Patients
}

\author{
H.-J. Lisch, K. Bolzano, J. Patsch, S. Sailer, and H. Braunsteiner \\ Medizinische Universitätsklinik, Innsbruck, Austria \\ Received: February 19, 1973, and in revised form: July 12, 1973
}

\begin{abstract}
Summary. The effect of calcium infusion on the intravenous glucose tolerance was tested in hypocalcaemic patients suffering from renal insufficiency. It was shown that the delayed glucose disappearance rate in uraemics could be improved $(p<0.005)$ by the infusion of calcium gluconolactobionate despite the fact that the serum concentrations of potassium, urea nitrogen, and the blood $\mathrm{pH}$ were not altered. The basal insulin concentration was significantly depressed by the calcium infusion $(p<0.02)$. The serum calcium concentration was significantly correlated to the glucose assimilation coefficient in the uraemic patients $(\mathrm{p}<0.01)$. -3 hypocalcaemic
\end{abstract}

patients without renal failure had a normal glucose tolerance and a normalization of the serum calcium concentration had no discernable effect. - A slight but significant decrease of the serum calcium concentration $(\mathrm{p}<0.01)$ by EDTA-Na $\mathrm{Na}_{2}$ in normocalcaemic patients did not change the intravenous glucose tolerance. - It is concluded that hypocalcaemia may be one of the causes for the abnormal glucose tolerance in chronic renal failure.

Key words : Calcium, EDTA, glucose tolerance, insulin, uraemia.
It has been long established that patients suffering from chronic renal failure may develop impaired carbohydrate tolerance [13]. However, the cause of this metabolic disturbance is not fully elucidated. On one hand, it has been suggested that delayed insulin release contributes to the abnormal glucose tolerance found in the uraemic state [17]. On the other hand, the suggestion was put forward that decreased sensitivity of the tissues to insulin action accounts for the delayed glucose disappearance in azotaemia $[14,20,2$, $10,11,18]$. The exact mechanism of this decreased sensitivity to insulin in uraemia remained, however, speculative.

The uraemic state is frequently accompanied by decreased serum calcium levels. Furthermore, calcium ions have been found to trigger the glucose-induced release of insulin from the pancreatic $\beta$-cell $[8,12]$. Therefore, it seems conceivable that hypocalcaemia inhibits the glucose induced release of insulin from the pancreas in vivo and may account for the decreased. glucose tolerance in uraemic patients.

In order to investigate the mechanism of the interaction between serum calcium concentration and glucose tolerance, calcium and insulin concentrations were measured during intravenous glucose tolerance tests in uraemic and normal patients.

\section{Materials and Methods}

\section{Selection of Patients}

Three groups of hospitalized patients of both sexes, aged between 23 and 76 years, underwent two intravenous glucose tolerance tests performed in the morning after an overnight-fast of $14 \mathrm{~h}$. The glucose tolerance tests were conducted on two consecutive days during an infusion of either saline or drug (see below).

The first group (Table $1 \mathrm{~A}$ ) consisted of 7 patients suffering from chronic renal failure with consistently subnormal serum calcium levels and with elevation of blood urea nitrogen in 6 cases. The patients were on a normocaloric diet poor in protein.

$30 \mathrm{~min}$ before the beginning of the glucose tolerance test either an infusion of saline solution or one of Calcium "Sandoz"R, 10\% (Calcium gluconolactobionate, $13.75 \mathrm{~g} / 100 \mathrm{ml}$ aq. bidest.) was given at an infusion rate of $2 \mathrm{ml} / \mathrm{min}$ using a motor pump. During the glucose tolerance test the infusion of saline or calcium was maintained at a rate of $0.2 \mathrm{ml} / \mathrm{min}$. Calcium gluconolactobionate was prefered to calcium chloride because of the irritating effect of the latter to veins and its acidifying action [19]. To exclude an effect of the gluconolactobionate salt of calcium on blood glucose concentration, the blood glucose was determined immediately before and $30 \mathrm{~min}$ after the beginning of the calcium infusion, i. e. at the start of the glucose tolerance test. There was no difference between the blood glucose concentrations before and after the infusion of calcium gltzconolactobionate (Blood glucose, $\mathrm{mg} / 100 \mathrm{ml}$, average value \pm SEM of the 7 nephropathic patients at the start of the infusion: $79 \pm 6 ; 30$ min later: $76 \pm 4 ; \mathrm{t}=1.45, p>0.1$ ).

The second group (Table $1 B$ ) comprised of 3 patients with low serum calcium due to other causes than renal insufficiency. They were on a normal diet. The experimental procedures were exactly the same as for the first group.

The third group (Table 1 C) consisted of 6 normocalcaemic patients without any history of renal disease. These patients were also on a normal diet. $60 \mathrm{~min}$ before the beginning of the glucose toler- 

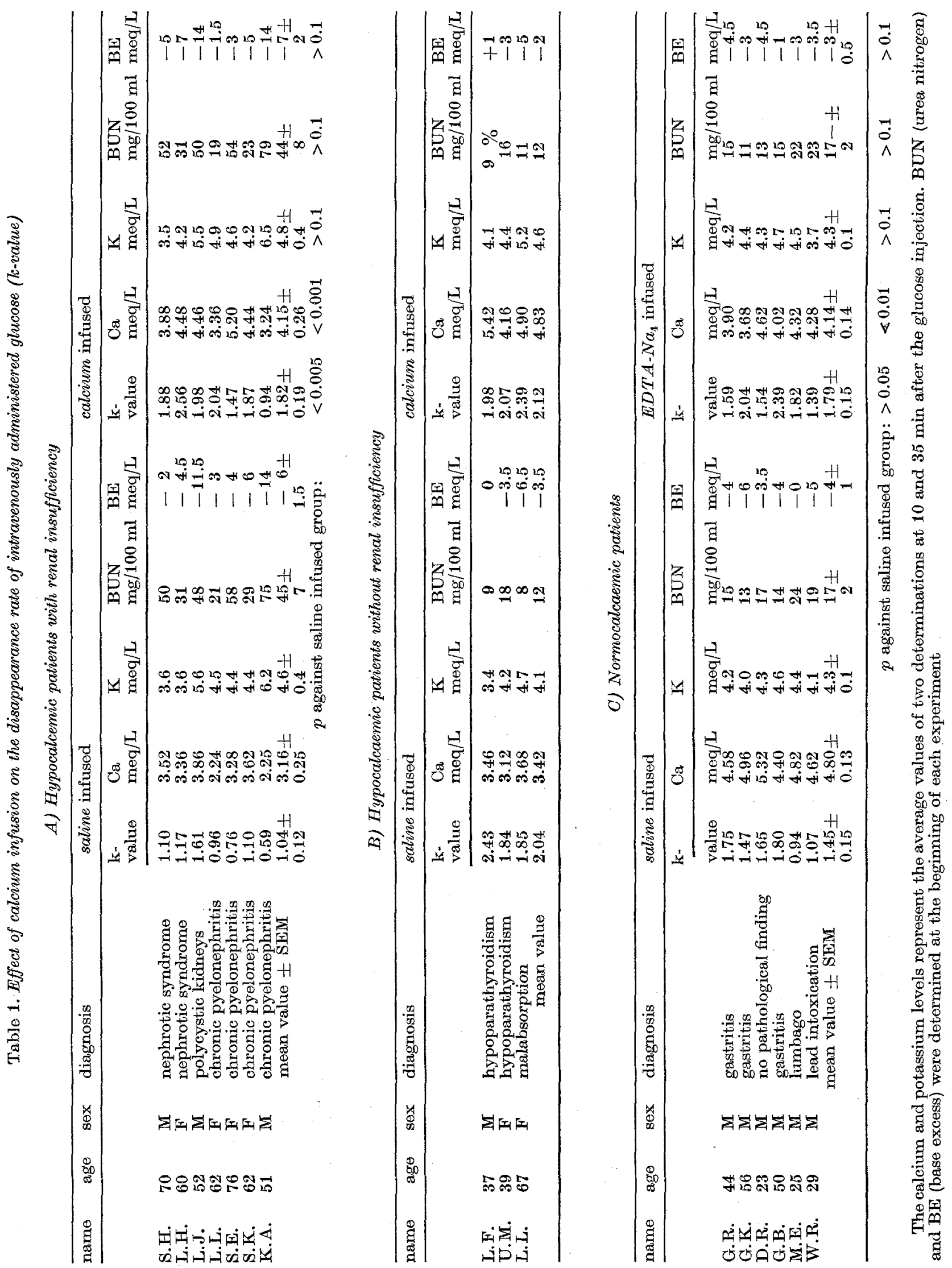
ance test they received an infusion of saline one with and one without $0.5 \%(w / v)$ EDTA-Na, at an infusion rate of $5 \mathrm{ml} / \mathrm{min}$. During the glucose tolerance test the infusion was maintained at $1 \mathrm{ml} / \mathrm{min}$.

\section{Chemical Determinations}

Blood glucose: o-toluidin method using an autoanalyzer (Technicon, Frankfurt a.M., G.F.R.).

Glucose assimilation coefficient k-"value": According to Conard [3].
The statistical examinations were performed using Student's t-test of the significance of a single mean.

\section{Results}

\section{A) Hypocalcaemic Patients with Renal Insufficiency}

Calcium infusion led to an elevation of the previously low serum calcium levels (Table 1 A). This increase of serum calcium was paralleled by a signifi-

Table 2. Serum insulin concentration $(\mu U / \mathrm{ml})$ during an intravenous glucose tolerance test after previous saline or calcium infusion in hypocalcaemic patients with renal insufficiency

\begin{tabular}{|c|c|c|c|c|c|c|c|c|c|c|c|c|c|c|c|c|c|c|c|c|}
\hline \multicolumn{11}{|c|}{ pretreatment saline infusion } & \multicolumn{10}{|c|}{ calcium infusion } \\
\hline $\begin{array}{l}\text { minutes afte } \\
\text { glucose } \\
\text { injection }\end{array}$ & -30 & 0 & 2 & 5 & 10 & 15 & 20 & 25 & 30 & 35 & -30 & 0 & 2 & 5 & 10 & 15 & 20 & 25 & 30 & 35 \\
\hline $\begin{array}{l}\text { name } \\
\text { S.H. } \\
\text { L.H. } \\
\text { L.J. } \\
\text { L.L. } \\
\text { S.E. } \\
\text { S.K. } \\
\text { K.A. } \\
\text { mean value } \\
\text { SEMI }\end{array}$ & $\begin{array}{r}18 \\
9 \\
17 \\
15 \\
27 \\
17 \\
26 \\
18 \\
2\end{array}$ & $\begin{array}{r}19 \\
8 \\
16 \\
24 \\
22 \\
9 \\
30 \\
18 \\
3\end{array}$ & $\begin{array}{r}36 \\
44 \\
62 \\
45 \\
60 \\
49 \\
59 \\
51 \\
4\end{array}$ & $\begin{array}{r}27 \\
40 \\
57 \\
51 \\
49 \\
25 \\
90 \\
48 \\
8 \\
p\end{array}$ & $\begin{array}{c}25 \\
- \\
46 \\
22 \\
45 \\
43 \\
75 \\
43 \\
8 \\
\text { gain }\end{array}$ & $\begin{array}{c}\overline{18} \\
46 \\
24 \\
42 \\
61 \\
38 \\
8 \\
\text { sal }\end{array}$ & $\begin{array}{r}26 \\
-39 \\
10 \\
47 \\
27 \\
55 \\
34 \\
7 \\
\text { ine i }\end{array}$ & $\begin{array}{c}- \\
\overline{39} \\
\overline{43} \\
22 \\
53 \\
39 \\
6 \\
\text { fuse }\end{array}$ & $\begin{array}{c}26 \\
17 \\
42 \\
19 \\
45 \\
23 \\
54 \\
32 \\
5 \\
\text { d gro }\end{array}$ & $\begin{array}{r}\overline{16} \\
39 \\
30 \\
57 \\
27 \\
61 \\
38 \\
7 \\
\text { ip: }\end{array}$ & $\begin{array}{c}22 \\
11 \\
15 \\
34 \\
32 \\
13 \\
35 \\
23^{a} \\
4 \\
>0.1\end{array}$ & $\begin{array}{c}21 \\
7 \\
10 \\
22 \\
22 \\
11 \\
32 \\
18^{\mathrm{a}} \\
3 \\
>0.1\end{array}$ & $\begin{array}{c}34 \\
47 \\
78 \\
67 \\
71 \\
41 \\
71 \\
58 \\
7 \\
>0.1\end{array}$ & $\begin{array}{c}45 \\
23 \\
82 \\
65 \\
64 \\
41 \\
71 \\
56 \\
8 \\
>0.1\end{array}$ & $\begin{array}{c}30 \\
13 \\
68 \\
38 \\
62 \\
33 \\
69 \\
45 \\
8 \\
>0.1\end{array}$ & $\begin{array}{l}30 \\
15 \\
60 \\
30 \\
57 \\
- \\
70 \\
44 \\
9 \\
>0.05\end{array}$ & $\begin{array}{r}25 \\
9 \\
62 \\
19 \\
50 \\
19 \\
74 \\
47 \\
8 \\
>0.1\end{array}$ & $\begin{array}{c}36 \\
12 \\
52 \\
15 \\
57 \\
19 \\
65 \\
37 \\
8 \\
>0.1\end{array}$ & $\begin{array}{c}31 \\
13 \\
57 \\
24 \\
56 \\
- \\
63 \\
41 \\
8 \\
>0.05\end{array}$ & $\begin{array}{l}- \\
\overline{84} \\
13 \\
50 \\
23 \\
62 \\
46 \\
13 \\
>0.1\end{array}$ \\
\hline
\end{tabular}

a The difference between the insulin level at -30 and $0 \mathrm{~min}$ in the calcium infused group was significant $(p<0.02)$

Serum potassium $(K)$ : The serum potassium concentration was determined by flame photometer (Evans Electroselenium Ltd., Halstead, England) at 10 and $35 \mathrm{~min}$ after the intravenous injection of glucose. The average value of these two levels is indicated in Table 1. Any significant difference between the serum potassium concentrations at 10 and $35 \mathrm{~min}$ after the injection of glucose was excluded by Student's t-test for all groups of glucose tolerance tests.

Serum calcium ( $\mathrm{Ca}$ ): The serum calcium concentration was estimated using the complexometric method of Gibitz [6] at 10 and 35 min after the glucose injection. The average value of these two levels is indicated in Table 1. Also here, significant differences between the 10 and 35 min level was excluded for all groups of glucose tolerance tests.

Urea nitrogen ( $B U N)$ : Blood urea nitrogen was determined at the beginning of the infusion (see above), i. e. 30 or $60 \mathrm{~min}$ before the glucose injection by means of the urease method [5] using an autoanalyzer (Technicon).

Serum insulin: Double antibody radioimmunoassay (9, as modified by 16). The determinations were performed $30 \mathrm{~min}$ before and $0,2,5,10,15,20,25,30$, and 35 min after the injection of glucose.

Base excess ( $B E$ ): The base excess was determined in blood at the beginning of the saline or drug infusion [1].

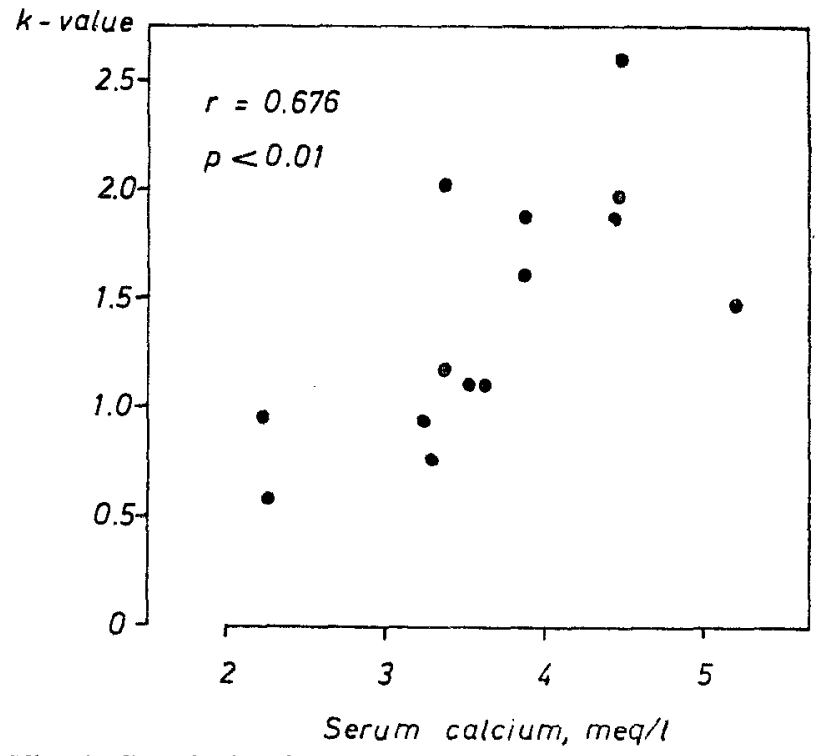

Fig. 1. Correlation between the serum calcium level and the corresponding glucose assimilation coefficient $(\mathrm{k}$ value) in patients suffering from chronic renal insufficiency (seo Table 1 A)

cant improvement in the delayed glucose disappearance rate ( $k$-value). The serum levels of potassium, urea nitrogen, and the base excess in blood did not change between the two glucose tolerance tests performed during saline or calcium infusions. A significant 
correlation was found between the serum calcium levels and the corresponding $\mathrm{k}$-values in patients with renal failure (Fig. 1).

Table 2 shows the individual insulin concentration values $30 \mathrm{~min}$ before and $0,2,5,10,15,20,25,30$, and 35 min after the beginning of the glucose tolerance tests during saline or calcium infusion. There was no significant difference of the serum insulin levels between the group treated with saline and the group receiving calcium infusion. However, a small but significant decrease of the serum insulin concentration was noted in the calcium treated group between the -30 and the 0 min values.

\section{B) Hypocalcaemic Patients without Renal Insufficiency}

The effect of calcium infusion on the glucose disappearance rate in hypocalcaemic patients suffering from hypoparathyroidism and malabsorption is shown in Table $1 \mathrm{~B}$. In these 3 hypocalcaemic cases the glucose disappearance rate was normal. This was not changed when the serum calcium concentration was normalized by calcium infusion. There was no correlation between calcium concentration and $k$-value in these patients $(r=0.071 ; p>0.1)$.

\section{C) Normocalcaemic Patients}

EDTA- $\mathrm{Na}_{2}$ infusion lowered the serum calcium concentration of 6 normocalcaemic patients slightly from 4.78 to $4.14 \mathrm{meq} / \mathrm{l}$ (Table $1 \mathrm{C}$ ). However, the glucose disappearance rate was not changed significantly by this procedure. There was no correlation between the serum calcium concentration and the corresponding $\mathrm{k}$-value in the 6 patients $(r=-0.512$; $0.10>p>0.05)$.

\section{Discussion}

In hypocalcaemic patients suffering from renal insufficiency a significant improvement of the delayed glucose disappearance rate by an intravenous calcium infusion was demonstrated, despite the fact that the concentrations of potassium, urea nitrogen, and the blood $\mathrm{pH}$ were not altered. Furthermore, a highly significant correlation could be shown between the serum calcium level and the $\mathrm{k}$-value in these patients. The insulin concentrations during the intravenous glucose tolerance test did not differ between the saline infused and the calcium infused group. However, the calcium infusion reduced the basal insulin concentration in the uraemic patients. Our findings could be interpreted as a facilitation of the peripheral action of insulin on the glucose uptake and/or as an improvement of the permeability of the cells for glucose by calcium. The reports on a reduced peripheral utilization of glucose in uraemic patients $[14,20,2,10,11,18]$ were confirmed by our observations. It is possible that correction of hypocalcaemia in patients suffering from renal insufficiency may improve some aspect of renal function and facilitate excretion of an insulin antagonist. This antagonist could be urea [11], in spite of the fact that urea concentration did not change during our experiments. Of course, many other antagonists to insulin action may play a role in renal insufficiency [18]. The lack of calcium effect in normal as well as hypocalcaemic patients without renal failure supports this hypothesis. The decrease of basal insulin concentration during infusion of calcium might be regarded as a result of facilitation of glucose transport into the cell in azotaemic patients.

The facilitation of the peripheral glucose uptake by calcium cannot be easily explained. It has been shown that in isolated fat cells, the addition of calcium chloride to the medium resulted in an enhancement of the binding of insulin to the fat cell membrane [4]. However, it has also been shown that adipose tissue involves only $5 \%$ of basal or insulin-stimulated glucose metabolism [15]. Supportive evidence for our interpretation that calcium ions facilitate the cellular glucose uptake was presented by Gould and Chaudry [7] in the isolated rat soleus muscle. In calciummagnesium-free media, basal glucose uptake was markedly depressed, but could be restored to near normal by the addition of calcium chloride.

In contrast to patients with renal insufficiency, persons with hypocalcaemia due to other causes (hypoparathyroidism, malabsorption) exhibited no glucose intolerance. When the serum calcium level was increased by calcium infusion, no remarkable change of the $\mathrm{k}$-value was noted. This suggests that hypocalcaemia can be considered as a causative factor for abnormal glucose tolerance only in uraemic patients.

In normocalcaemic patients, a slight but significant decrease of the serum calcium concentration was achieved by EDTA-Na, $\mathrm{N}_{2}$ fusion. This was without influence on the glucose disappearance rate, but it must be noted that the decrease of the calcium concentration in these individuals was small.

In summary, our results yield evidence for the participation of hypocalcaemia as a causative factor for the abnormal glucose tolerance in uraemic patients.

\section{References}

1. Astrup, P., Siggard-Andersen, O.: Micromethods for measuring acid-base values of blood. Advanc. clin. Chem. 6, 1-28 (1963)

2. Cerletty, J.M., Engbring, N.H.: Azotemia and glucose intolerance. Ann. int. Med. 66, $1097-1108$ (1967)

3. Conrad, V.: Mésure de l'assimilisation du glucose. Bases théoriques et applications cliniques. Acta med. belg. ed., Bruxelles, 1955

4. Cuatrecasas, P.: Properties of the insulin receptor of isolated fat cell membranes. J. biol. Chem. 246, $7265-7274(1971)$

5. Fawcett, J.K., Scott, J.E.: A rapid and precise method for the determination of urea. J. clin. Path. 13, $156-159(1960)$ 
6. Gibitz, H.: Vergleichende Untersuchungen über die direkt komplexometrische Serumkalziumbestimmung ohne vorhergehende Oxalatfällung. Wien. Z. inn. Med. 41, 216-221 (1960)

7. Gould, M.K., Chaudry, I.H.: The action of insulin on glucose uptake by isolated rat soleus muscle. (1) Effects of cations. Biochim. biophys. Acta (Amst.) 215, 249-257 (1970)

8. Grodsky, G.M., Bennett, L.L.: Insulin secretion from the isolated pancreas in absence of insulinogenesis. Effects of glucose. Proc. Soc. exp. Biol. (N.Y.) 114, $769-771$ (1963)

9. Hales, C.N., Randle, P.J.: Immunoassay of insulin with insulin antibody precipitate. Biochem. J. 88, $137-146(1963)$

10. Horton, E.S., Johnsen, C., Lebovitz, H.E.: Carbohydrate metabolism in uremia. Ann. int. Med. 68, $63-74(1968)$

11. Liebermeister, H., Daweke, H., Gebhardt, K., Grüneklee, D.: Impaired glucose tolerance in uremia: Inhibition of insulin effect by urea. (abstract). 5th Annual meeting of the EASD, Montpellier 1969

12. Milner, R.D.G., Hales, C.N.: The role of ealcium magnesium in insulin secretion from rabbit pancreas studied in vitro. Diabetologia 3, 47-49 (1967)

13. Myers, V.C., Bailey, C.V.: The Lewis and Benedict method for the estimation of blood sugar, with some observations obtained in disease. J. biol. Chem. 24, $147-161$ (1916)

14. Perkoff, G.T., Thomas, C.L., Newton, J.D., Sellman, J.C., Tyler, F.H.: Mechanism of impaired glucose tolerance in uremia and experimental hyperazotemia. Diabetes 7, 375-383 (1958)

15. Rabinowitz, D.: Some endocrine and metabolic aspects of obesity. Ann. Puev. Med. 21, 241-258 (1970)

16. Sailer, S., Bolzano, F., Sandhofer, F., Spath, P., Braunsteiner, H.: Triglyceridspiegel und Insulinkonzentration im Plasma nach oraler Glukosegabe bei Patienten mit primärer kohlenhydratinduzierter Hypertriglyceridämie. Schweiz, med. Wschr. 98, $1512-1518(1968)$

17. Spergel, G., Bleicher, SJ., Goldberg, M., Adesman, J., Goldner, M.C.: The effect of potassium on the impaired glucose tolerance in chronic uremia. Metabolism 16, 581 - 585 (1967)

18. Spitz, I.M., Rubenstein, A.H., Bersohn, I., Abrahams, C., Lowy, C.: Carbohydrate metabolism in renal disease. Quart. J. Med. 39, 201-226 (1970)

19. Welt, L.G., Blythe, W.B.: Cations: Calcium, magnesium, barium, lithium, and ammonium. In the Pharmacological Basis of Therapeutics. Ed. L.S. Goodman and A. Gilman, Third Edition, p. 799. New York: The Macmillan Company 1965

20. Westervelt, F.B., Schreiner, G. E.: The carbohydrate intolerance of uremic patients. Ann. int. Med. 57, $266-276(1962)$

Dr. H.-J. Lisch

Med. Univ.-Klinik

A-6020 Innsbruck

Austria 